\title{
Biografia
}

BIOGRAFIA DE ELAIR DINIZ BRASILEIRO

(Disponível em <http://recantodasletras.vol.com.br/autores/karol242424>)

Maria da Penha Leite (1)

A biografia em tela, discorre sobre a vida de Elair Diniz Brasileiro, Paraibano, nascido em Canto de Feijão, município de Santa Helena,em 4 de agosto de 1939.

Resgatando seu passado histórico, relata a autora ser este sertanejo, primogênito de uma família de oito filhos. Seu pai Eládio de Almeida Brasileiro, era natural de Tefé no estado da Amazônia, onde viveu até o nascimento de seu quinto filho. Descendente de família humilde, com muitas necessidades financeiras, migraram para o Nordeste, mais especificamente para o município de Missão Velha, interior do Ceará.

Por dificuldades diversas, bem precocemente perdeu a mãe e foi morar com um tio em Baixio estado do Ceará, onde inicia sua vida laboral como vendedor em uma loja de tecidos. No trabalho conheceu sua futura esposa,que morava na cidade vizinha, filha única de um homem muito influente na política,o senhor Francisco Josias Diniz, na época chamada Canto do Feijão, hoje conhecida como Santa Helena Paraíba. Os pais de Elair, Sr. Eládio e Sra. Nair casaram em novembro de 1937. Desta união nasceram oito filhos, Elair, foi o mais velho e por isso, seu nascimento veio carregado de muitas expectativas de alegria para a família. Sempre demonstrou entusiasmo, destacando-se em diversas atividades.

Aos 34 anos casa-se com a senhorita Maria Elizabete Soares, em maio de 1973. Ela, filha de uma da família tradicional de Santa Helena, filha do casal José Soares de Sousa e Isabel Correia Lima. Professora e funcionária pública. Deste relacionamento nasceram cinco filhos. Elair Soares Brasileiro, nasce como quarto filho do casal.

A autora cita diversas passagens da sua vida laboral, onde exerceu diversas profissões, dentre as quais, farmacêutico, agricultor, comerciante e finalmente administrador público. Na sua obstinação pelo trabalho emerge um cidadão solidário e afetuoso e comprometido com o social.

Segundo a autora, um homem realizado em suas "grandes paixões", o serviço público e a vontade de produzir e inovar.

A autora registra que o senhor Elair Diniz Brasileiro, decide ingressar na política a convite de um amigo, Daciano Soares da Silva.

Em novembro de 1962, instala-se em Santa Helena, a $1^{\text {a }}$ Câmara de Vereadores deste município. Nesta mesma data foi realizada a eleição para a mesa da Câmara, onde, já eleito Vereador, foi eleito também ocupar a Vice-Presidência da casa. Em meados do ano seguinte, foi eleito Presidente desta casa, por um período de um ano. 
Seu trabalho como representante do povo e dos colegas administradores municipais, o levaram novamente a primeira Secretaria da Câmara Municipal. Desta feita, responsável por relatar e acompanhar todos os trabalhos realizados durante as reuniões da casa. Participou de diversas comissões como a Comissão de Justiça e Paz.

Empenhou-se na criação e elaboração da Legislação Municipal de Santa Helena, conquistou o respeito entre os colegas.

Em junho 1965, foi conduzido a Presidencia da Câmara Municipal da Casa Abidias, em março de 1965. No ano seguinte, em 1966, logra êxito nas eleições municipais para Prefeito logra êxito nas eleições municipais para Prefeito. Foi o início de uma longa vida pública.

Em novembro de 1972, foi novamente diplomado Gestor Municipal de Santa Helena, através de eleições livres e diretas. Dez anos depois, em 1982, parte para seu terceiro mandato como Gestor Municipal de Santa Helena, onde centra seu foco de atenção no desenvolvimento das questões públicas da saúde.

Mais dez anos se passam e novamente, em 1992 é aclamado para o seu quarto mandato como Prefeito de Santa Helena. Desta vez, centra sua atenção para a educação aos menos favorecidos.

Volta a exercer a liderança municipal em seu quinto mandato em Janeiro de 2004. Desta feita focou sua atenção na zona rural, realizando parcerias, investindo em transporte, reformas nas escolas, merenda escolar, capacitação de professores, de forma a oferecer um atendimento digno aos que dele carecem.

Por todos esses feitos, a autora considera Elair Diniz Brasileiro um homem que viveu além do seu tempo, fecundando idéias inovadoras para sua época. De simples garoto do interior, passou a administrar um Município com o apoio da sociedade.

A autora acredita que este homem público, pelo seu carisma e pelo legado de bons serviços prestados, não vai parar por aí. Ele deve seguir o destino dos guerreiros, daqueles que têm um propósito e esforça-se por realizar. Afinal, há sempre muitos desafios a vencer.

\section{Sobre a Autora:}

(1) Maria da Penha Leite é Licenciada em Letras pela Universidade Federal da Paraíba, com especialização em Língua Espanhola pela Universidade Federal do Ceará. É Professora da Rede Pública do Estado da Paraíba. Atualmente cursa Mestrado em Ciências da Educação pela Faculdad San Carlos Paraguai.

E-mail: brilho-26@hotmail.com

Site da autora: http://recantodasletras.vol.com.br/autores/karol242424

\section{Como citar este artigo (Formato ISO):}

LEITE, M.P. Biografia de Elair Diniz Brasileiro. Id on Line Revista de Psicologia, Fevereiro de 2011, vol.1, no.13, p.103-104. ISSN 1981-1189. 